\title{
Praktijk Praktijk
}

\section{Twee jaar campagne Gezond Gewicht: de balans}

Marieke W. Verheijden, ${ }^{1}$ Vera C.Slootweg, ${ }^{1}$ Margret Ploum, ${ }^{2}$ Andrea Werkman ${ }^{2}$

De meerjarencampagne Gezond Gewicht van het Voedingscentrum bestaat onder andere uit massamediale uitingen (spots op radio en $T V$ en online ondersteuning) die Nederlanders wijzen op het belang van een gezonde energiebalans. Zo worden ze gestimuleerd zich bewust te worden van het belang van een gezond gewicht en aangezet om hier actief mee bezig te zijn. Met de campagne wordt daarbij gestreefd naar drie gedragingen: gezond eten, voldoende bewegen en het compenseren van incidentele momenten van overconsumptie (de Balansdag). De campagne richt zich primair op Nederlanders tussen 20-55 jaar met een BMI van 18,5-28. De campagne wordt halfjaarlijks gemonitord door TNO Kwaliteit van Leven.

\section{AANLEIDING EN PROBLEEMANALYSE}

Overgewicht is een groeiend maatschappelijk probleem in Nederland. Dat overgewicht zowel op de korte als lange termijn tot directe gezondheidsproblemen leidt is algemeen bekend. ${ }^{1}$ Het belang van het behouden van een gezond gewicht is dus evident. Omdat een gezond gewicht het resultaat is van de juiste balans tussen energie-inneming en energieverbruik (energiebalans), zouden preventieve projecten op dit terrein zich moeten richten op het concept energiebalans.

Het Voedingscentrum probeert met verschillende projecten op integrale manier het probleem van overgewicht aan te pakken. In 2002 is gestart met de campagne Maak je niet dik!. Met deze campagne werd gestreefd naar agendering en bewustwording van het probleem

\footnotetext{
TNO Kwaliteit van Leven, Leiden

2 Stichting Voedingscentrum Nederland, Den Haag
}

overgewicht. Al snel werd duidelijk dat de doelstellingen van deze massamediale campagne gehaald waren. Een grote meerderheid (96\%) van de doelgroep was zich bewust van het belang van een gezond gewicht en $87 \%$ vond het belangrijk om gewichtsstijging te voorkómen. Wel werd duidelijk dat de kloof tussen goed weten en goed doen nog te groot was. ${ }^{2}$ Mede op basis van deze inzichten is de meerjarencampagne Gezond Gewicht ontwikkeld, waarmee gestreefd wordt naar energiebalans als middel om een gezond gewicht te behouden en zo het aantal Nederlanders met een gezond gewicht te stabiliseren. Het Voedingscentrum heeft het concept energiebalansgedrag in deze campagne vertaald naar: gezond eten volgens de Schijf van Vijf, voldoende bewegen en compensatie middels een Balansdag wanneer dat nodig is. ${ }^{2}$

\section{Opbouw campagne Gezond Gewicht} De campagne Gezond Gewicht richt zich op het snijvlak van weten en doen, met behulp van een interventiemix die 'het doen' vergemakkelijkt. De campagne loopt van 2007 tot en met 2010 waarbij het basisconcept (energiebalans) gedurende de gehele looptijd centraal staat. Deze campagne richt zich primair op de volwassen Nederlandse bevolking van twintig tot vijfenvijftig jaar met een gezond gewicht of licht overgewicht. Bovenop de campagnebasis heeft Gezond Gewicht jaarlijkse aandachtsgebieden. In 2008 was in de campagne bijzondere aandacht voor laaggeschoolde mannen in de werksetting. Reden hiervoor is het hardnekkige verschil in gezondheid in Nederland tussen de verschillende sociale klassen. Laagopgeleiden leven korter en hebben meer gezondheidsproblemen dan hoogopgeleiden. ${ }^{1}$ Mannen wer- den vooral benaderd omdat zij vaker overgewicht hebben en nauwelijks vatbaar lijken voor gezondheidsvoorlichtingsboodschappen. ${ }^{2}$ Deze doelgroep is ook gekozen omdat recent onderzoek onder werknemers uit diverse branches liet zien dat meer dan één op de drie werknemers te dik is. ${ }^{3}$ Bovendien is de werkplek een setting waar een groot deel van de volwassen Nederlandse bevolking vrijwel dagelijks te vinden is.

In 2009 en 2010 staat de rol van ouders centraal. Uit de literatuur blijkt dat voorbeeldgedrag van ouders een cruciale rol speelt voor zowel eten als bewegen. Voor bewegen geldt: 'Belangrijker dan de samenstelling van het gezin en de sociaal-economische status van de ouders, lijken de voorbeelden en stimulansen die de kinderen thuis krijgen'. ${ }^{4}$ Ouders hebben invloed op de ontwikkeling van voedingsvoorkeuren en eetgedrag van hun kinderen doordat zij bepaalde voedingsmiddelen ter beschikking stellen en omdat zij een voorbeeld zijn. $^{5}$

Mede op basis van de ervaringen met de Maak je niet dik! campagne wordt in de Gezond Gewicht campagne nadrukkelijk aandacht besteed aan het realiseren van voldoende persoonlijke relevantie van de campagne-uitingen, het geven van concrete/praktische ondersteuning voor gewichtsbehoud op de korte èn de lange termijn, en het ontwikkelen van specifieke strategieën voor subgroepen van de bevolking.

\section{AANPAK}

Door massamediale aandacht wordt geprobeerd de doelgroep te bereiken. In radio- en tv-spotjes wordt het belang van een gezonde energiebalans onderstreept. Een gezonde energiebalans wordt hierbij in verband gebracht met "je 
lekker voelen"; in de uitingen wordt weinig tot geen aandacht besteed aan het belang van energiebalans voor een gezond gewicht. Er wordt nadrukkelijk naar gestreefd om de persoonlijke relevantie van de spots èn van de boodschap zo hoog mogelijk te maken. De massamediale campagne wordt ondersteund via internet, waar de consument terecht kan voor concrete hulpmiddelen. Een hulpmiddel dat ondermeer inzet op het geven van hulp bij het omzetten van intenties in gedrag is de 'Gezond Gewicht Assistent'. Het gaat hierbij om interactief advies op maat met persoonlijke feedback, onder andere gericht op het verschaffen van inzicht in de eigen emoties rond eten en bewegen en het mobiliseren van sociale steun. Deze Gezond Gewicht Assistent wordt nu onderzocht en is naar verwachting najaar 2009 beschikbaar. Ook worden nieuwsbrieven en simpele tests (caloriechecker, Balansdagtest) gebruikt om consumenten te binden en de informatie persoonlijker te maken. Daarnaast heeft de campagne in de eerste twee jaren aanzienlijke 'free publicity' opgeleverd, bijvoorbeeld in huis aan huis bladen en magazines van supermarktketens.

\section{LOKALE INBEDDING}

In de Gezond Gewicht campagne wordt op verschillende manieren gestreefd naar lokale inbedding. Zo is bijvoorbeeld een denksessie georganiseerd met vertegenwoordigers van GGD'en waarin de plannen uiteengezet zijn. De respons van deze vertegenwoordigers (op basis van hun ervaring met de doelgroep en hun inschatting van de behoeften) is gebruikt bij het ontwikkelen van de campagne. Ook wordt de suggestie van deze vertegenwoordigers meegenomen om een wijzer te maken over feiten en fabels, omdat ouders hierover vaak onzeker zijn. Daarnaast is Eetplezier en Beweegkriebels beschikbaar, een workshop over het belang van gezond eten en voldoende bewegen voor ouders van jonge kinderen. Kinderdagverblijven, peuterspeelzalen en voorscholen kunnen de workshop inzetten om ouders te helpen bij het aanleren van een gezonde leefstijl bij hun kinderen. Er is een pakket met een dvd beschikbaar waarin, aan de hand van herkenbare opvoedthema's, praktische tips worden gegeven over eet- en beweeggedrag bij kinderen tot vier jaar. Op de dvd worden zes thema's uitgelicht: omgaan met strijd aan tafel; lekker spelen en bewegen; voorbeeldfunctie van ouders; belonen zonder snoep en frisdrank; televisie kijken en computeren; en tips voor een actieve dag.

\section{ONDERZOEKSOPZET}

TNO Kwaliteit van Leven draagt zorg voor de monitoring van de campagne Gezond Gewicht. Hiertoe wordt een cohort volwassen Nederlanders gedurende vier jaar (acht metingen) gevolgd. Aan de eerste meting van het cohort (november 2007) namen ruim 1000 volwassenen deel. Ook worden acht cross-sectionele metingen uitgevoerd bij drie subgroepen van de bevolking; deelnemers in de leeftijd van 18-55 jaar (minimaal 500 per meting), deelnemers in de leeftijd van 56-75 jaar (minimaal 300 per meting) en een groep mannen met een lage economische status (lage SES mannen, minimaal 200 per meting). De deelnemers worden benaderd via een onderzoeksbureau. Zwangere vrouwen of vrouwen die recent bevallen zijn worden uitgesloten van deelname. Gegevens worden verzameld met digitale en/of schriftelijke vragenlijsten.

Specifieke (onderzoeks)vragen van de Monitor Gezond Gewicht zijn gebaseerd op de theorie van gepland gedrag ${ }^{6}$ en diverse theoretische modellen en inzichten over zelfregulatie. ${ }^{7,8}$ Het hoofdgedrag (energiebalans) is hierbij geoperationaliseerd als: "letten op de balans tussen eten en bewegen”. Daarnaast wordt er aandacht geschonken aan drie subgedragingen: letten op wat en hoeveel je eet, voldoende bewegen (volgens de Nederlandse Norm Gezond Bewegen voor volwassenen: op minimaal vijf dagen per week minimaal 30 minuten matig intensief bewegen) en compenseren van incidentele momenten van overeten (met een Balansdag of andere strategie).

De campagne na de eerste meting (nulmeting) was erop gericht om het concept energiebalans onder de aandacht te brengen bij de algemene volwassen bevolking (tabel 1). Het concept werd daarbij toegelicht aan de hand van tekst en afbeeldingen. De campagne-uitingen na de tweede meting waren gericht op mannen met een lage sociaal-economische status. In de uitingen werd vanuit het "gevaar" van een buikje aandacht besteed aan de Balansdag als middel om te compenseren na dikmakende verleidingen. Tussen meting 3 en meting 4 vonden geen campagne-uitingen plaats.

\section{ONDERZOEKSRESULTATEN}

In de periode tot en met april 2009 hebben in de Monitor Gezond Gewicht vier metingen plaatsgevonden; gegevens van de eerste drie metingen zijn reeds geanalyseerd. In dit artikel worden slechts beknopte resultaten van het cohortonderzoek gepresenteerd. Uitgebreidere resultaten worden gepresenteerd in het onderzoeksrapport over de eerste drie metingen. ${ }^{9}$

Voor het cohort werd een (wat betreft leeftijd, geslacht, opleidingsniveau, etniciteit en geografische regio representatieve) groep van 1240 volwassen Nederlanders benaderd. Hiervan vulden 1030 personen de eerste vragenlijst in. De tweede vragenlijst werd ingevuld door 935 personen en de derde vragenlijst door 843 personen. Na drie metingen was de respons dus $68 \%$ (843/1240). Bij alle drie de metingen was ongeveer de helft van de ondervraagden man. Ongeveer $45 \%$ van de deelnemers had een normaal gewicht; de anderen hadden overgewicht ( $40 \%)$ of obesitas (15\%).

Het kennisniveau over het concept energiebalans was hoog; driekwart van de deelnemers wist voorafgaand aan de eerste campagne wat met de term energiebalans bedoeld werd. Tussen de eerste $(75 \%)$ en de derde meting $(77 \%)$ nam dit aandeel nog zeer licht toe. Bijna een kwart van de deelnemers had voor-

Tabel 1 Planning van de campagneperiodes (C) en metingen (M) in het kader van de campagne Gezond Gewicht.

\begin{tabular}{lllll}
\hline $\begin{array}{l}\text { M 1 } \\
\text { nov 07 }\end{array}$ & jan 08 & M 2 & C 2 & M 3 \\
& Campagne energiebalans & & juni 08 en okt 08 & nov 08 \\
& & Campagne Overwin de & $\begin{array}{l}\text { Campagne Battle de buik } \\
\text { met een Balansdag }\end{array}$ \\
\hline
\end{tabular}


afgaand aan de tweede meting een TVspot over gezond eten en bewegen gezien. Eén procent van de deelnemers noemde hierbij spontaan de algemene spot over energiebalans van de Gezond Gewicht campagne. Nog eens drie procent van de deelnemers herkende de spot na het zien van een afbeelding. Deelnemers die de spot gezien hadden, beoordeelden deze over het algemeen als duidelijk, nuttig en goed. Acht procent van de deelnemers had in de periode tussen meting 2 en meting 3 een tvspot gezien over de balans tussen gezond eten en bewegen. Drie procent noemde spontaan de spot Battle de Buik met een Balansdag; nog eens $16 \%$ herkende de spot na het zien van een afbeelding. Deelnemers beoordeelden het spotje vooral als duidelijk en opvallend.

Het thema energiebalans werd door veel deelnemers relevant gevonden. Minder deelnemers gaven echter aan dat de televisiespots voor hen persoonlijk relevant waren ( $35 \%$ vond de algemene spot over energiebalans (heel) belangrijk voor zichzelf; voor de spot over Battle de Buik met de Balansdag, die specifiek gericht was op lage SES mannen, was dit $28 \%$ ). Het percentage deelnemers dat de spots (zeer) belangrijk vond voor mensen in hun omgeving was $43 \%$ (energiebalans) en $44 \%$ (Battle de Buik met een Balansdag).

De data die in de Monitor Gezond Gewicht verzameld zijn, worden naast hun gebruik voor evaluatiedoeleinden ook gebruikt voor wetenschappelijke doeleinden. Samen met de Universiteit van Amsterdam wordt bijvoorbeeld onderzocht of en in welke mate eventuele veranderingen over de tijd in (determinanten van) gedrag plaatsvinden. In samenwerking met de Radboud Universiteit Nijmegen wordt de rol van lijngericht, extern en emotioneel eetgedrag bij de preventie van ongewenste gewichtsstijging onderzocht. Ook voor het beantwoorden van andere onderzoeksvragen kunnen de data in overleg beschikbaar worden gesteld aan derden.

\section{CONCLUSIE}

De blootstelling aan uitingen van de massamediale campagne is bij de eerste twee campagneperiodes gering geweest. Slechts een beperkt deel van de deelnemers noemde de Gezond Gewicht campagne spontaan. Het percentage deelne- mers dat een afbeelding van de campagnespots herkende èn deze naar eigen zeggen gezien had, lag hoger. Ook productreclames van commerciële partijen (vaak levensmiddelenconcerns) werden zeer regelmatig genoemd. Vooralsnog is de persoonlijke relevantie van de campagne-uitingen beperkt; zij sluiten nog beperkt aan bij de manier waarop de doelgroep omgaat met het thema energiebalans, dat op zichzelf relevant gevonden wordt. Bij het ontwikkelen van toekomstige campagne-uitingen wordt hieraan opnieuw nadrukkelijk aandacht besteed. Vervolgmetingen moeten meer inzicht geven in of, op welke manier en in welke mate blootstelling aan de campagne Gezond Gewicht leidt tot gezond energiebalansgedrag.

\section{TOEKOMST}

De campagne Gezond Gewicht loopt tot en met 2010. Uit de eerste drie metingen bleek dat de overgrote meerderheid van de ondervraagde Nederlanders goed op de hoogte was van het belang van een gezonde energiebalans en een gezond gewicht. Het is daarom de vraag of hierin tijdens de resterende campagneperiode nog verbeteringen zullen optreden. Toch blijft agendasetting een belangrijk doel van de campagne, om te voorkómen dat de aandacht verslapt. Tegelijkertijd streeft het Voedingscentrum naar verdere focus. Deze komt de komende tijd te liggen op de doelgroep ouders om hen aan te zetten hun eigen (voorbeeld)gedrag te toetsen en waar nodig bij te stellen. De eerdere aandacht voor mannen, in het bijzonder met een lage sociaaleconomische status, krijgt zo ook een vervolg. Uit onderzoek blijkt dat mannen aanspreekbaar zijn op hun vaderrol waar het gaat om het welzijn en de gezondheid van hun kinderen. ${ }^{10}$

De tussentijdse resultaten van de monitor Gezond Gewicht zullen mede gebruikt worden om de uitingen in de resterende campagneperiode vorm te geven. Gezien de hoge persoonlijke relevantie van het thema Gezond Gewicht en de aanzienlijk lagere persoonlijke relevanties van de spots over dit thema tot nu toe, blijft het een uitdaging om de massamediale uitingen zó vorm te geven dat zij de beoogde doelgroep bereiken, aanspreken èn blijvend aanzetten tot energiebalansgedrag. Het Voedingscentrum verwacht de persoonlijke relevantie van de geplande spots over voorbeeldgedrag te kunnen verhogen door ouders te laten zien wat het effect van hun opvoedstijl en voorbeeldgedrag is op welzijn en gezondheid van hun kinderen. Kinderen zijn immers aantoonbaar persoonlijk relevant voor ouders.

De laatste meting van het onderzoek vindt in 2011 plaats. In de eindrapportage zal aandacht worden besteed aan de mate waarin gedurende de campagne veranderingen zijn opgetreden in (determinanten van) energiebalansgedrag.

\section{ABStRact}

Two years into the Healthy Weight campaign: taking stock

The Healthy Weight campaign was launched by the Netherlands Nutrition Centre in 2007 in an attempt to assist normal weight and mildly overweight $(\mathrm{BMI}<28)$ Dutch adults in maintaining a healthy weight. The campaign consists of commercials (radio and TV), supported by webbased behaviour change tools and free publicity. This article describes experiences two years into the campaign.

Keywords: mass media, energy balance, campaign

\section{LITERATUUR}

1. RIVM. Volksgezondheid Toekomst Verkenning. Bilthoven: RIVM, 2006.

2. Voedingscentrum. Gezond Gewicht. Den Haag; 2006.

3. Hildebrandt V, Jans M. Grote verschillen in leefstijl tussen beroepen en branches: de bankier beweegt te weinig, zijn chauffeur eet te veel. Arbo 2007;1:22-5.

4. Frelier M, Janssens JW. Sporten en bewegen: waarom doen kinderen het (niet)? 's-Hertogenbosch: Mulier Instituut, 2007.

5. Savage JS, Fisher JO, Birch LL. Parental influence on eating behavior: conception to adolescence. J Law Med Ethics 2007;3522-34.

6. Ajzen I. The theory of planned behavior. Organ Behavior Human Decision Processes 1991;50:179-211.

7. Ryan RM, Deci EL. An overview of self-determination theory. In: Deci EL, Ryan RM (eds). Handbook of selfdetermination research. Rochester, NY: University of Rochester Press, 2002, pp. 3-33.

8. Silva MN, Markland D, Minderico CS 
et al. A randomized controlled trial to evaluate self-determination theory for exercise adherence and weight control: rationale and intervention description. BMC Public Health 2008; 8:234.

9. Schermers $P$, Van Kesteren $N$, Verheijden MW. Rapportage over meting
1 tot en met 3 van de Monitor Gezond Gewicht. Leiden: TNO Kwaliteit van Leven, 2009.

10. Mensink F. Hoe kunnen jongvolwassen mannen beter bereikt worden met voorlichting over voeding? Kwalitatief en kwantitatief onderzoek naar effectieve voorlichtingsmetho- den voor jongvolwassen mannen.

Den Haag: Voedingscentrum, 2007.

\section{CORRESPONDENTIEADRES}

Dr. ir. M.W. (Marieke) Verheijden, TNO Kwaliteit van Leven, Postbus 2215, 2301 CE Leiden, e-mail: marieke.verheijden@tno.nl 